\title{
Penyuluhan Tentang Penyakit Diabetes Melitus dan Senam Diabetes Melitus Pada Ibu-ibu Lansia di Jatibening Bekasi
}

\author{
Tuti Wiyati $^{1 *}$, Ni Putu Ermi Hikmawanti ${ }^{1}$, Nurhasnah ${ }^{1}$ \\ ${ }^{1}$ Fakultas Farmasi dan Sains, Universitas Muhammadiyah Prof. Dr. Hamka, Jl. Delima II/IV Jakarta Timur \\ *Email koresponden: tuti.wiyati@uhamka.ac.id
}

\begin{abstract}
Abstrak
Jumlah penderita Diebetes Melitus (DM) hingga saat ini masih didominasi usia lansia. Usia lansia diketahui banyak mengalami kemunduran aktivitas fisiologis tubuh. Beberapa masalah yang kerap muncul pada usia lanjut, yang disebut sebagai a series of I's mulai dari immobility (imobilisasi), instability (instabilitas dan jatuh), incontinence (inkontinensia), intellectual impairment (gangguan intelektual), infection (infeksi), impairment of vision and hearing (gangguan penglihatan dan pendengaran), isolation (depresi), inanition (malnutrisi), insomnia (ganguan tidur), hingga immune deficiency (menurunnya kekebalan tubuh) Hal inilah yang menjadi perhatian kami pada ibu-ibu kelompok lansia komplek Depkes I Jatibening Bekasi. Komplek perumahan ini dihuni oleh lebih dari $70 \%$ usia lansia. Target yang ingin dicapai adalah meningkatnya pemahaman dan pengetahuan terkait penyakit diabetes mellitus. Selain itu juga membangun kesadaran untuk pola hidup yang lebih baik dengan kegiatan promotif berupa senam diabetes melitus yang bisa dilakukan oleh para ibu-ibu lansia di rumah. Metode pelaksanaan kegiatan pengabdian ini dilakukan dengan cara yang sederhana yakni dengan metode ceramah (pemberian materi), pemutaran video dan praktek/simulasi senam diabetes melitus. Peningkatan pemahaman perserta dipantau melalui pre-post-test menggunakan kuesioner. Kegiatan ini memberikan kesan yang positif dan bermanfaat bagi para peserta penyuluhan. Ibu-ibu peserta sangat antusias saat diskusi materi. Hasil pre-post-test menunjukkan bahwa pemahaman peserta baik tentang penyakit DM. Peserta juga akhirnya memahami salah satu olahraga sederhana berupa senam kaki diabetes melitus.
\end{abstract}

Kata kunci: diabetes melitus, lansia, senam diabetes melitus.

\begin{abstract}
The number of people with Diebetes Melitus (DM) is still dominated by the elderly. The age of the elderly is known to experience a lot of deterioration in the physiological activities of the body. Some of the problems that often arise in old age, which are referred to as a series of I's, range from immobility, instability (instability and fall), incontinence (incontinence), intellectual impairment, intellectual infection, impairment of vision. and hearing (impaired vision and hearing), isolation (depression), inanition (malnutrition), insomnia (sleep disturbances), to immune deficiency (decreased immunity) This is what concerns us in the elderly group of Komplek Depkes I Jatibening Bekasi. This place is inhabited by more than $70 \%$ of the elderly. The target to be achieved is increasing understanding and knowledge related to diabetes mellitus. In addition, it also builds awareness for a better lifestyle with promotive activities in the form of diabetes mellitus exercises that can be done by elderly mothers at home. The method of carrying out this service activity is carried out in a simple way namely by the lecture method (giving material), video screening and practice / simulation of diabetes mellitus gymnastics. Increased understanding of participants was monitored through pre-post-test using a questionnaire. This activity gives a positive and beneficial impression for the counseling participants. The participants were very enthusiastic when discussing the material. The results of the pre-post-test showed that participants' understanding was good about DM disease. Participants also finally understood one simple exercise in the form of diabetes mellitus foot exercises.
\end{abstract}

Keywords: diabetes melitus, lansia, senam diabetes melitus.

Format Sitasi: Paulina L. \& Pramudiani P. (2018). Pembelajaran Karakter Melalui Media Dongeng pada PAUD Formal Binaan I Dan Binaan III Ciracas Jakarta Timur. Jurnal SOLMA, 01(1), 225-232. Doi: http://dx.doi.org/10.29405/solma.v7i2.1663.

Diterima: 14 Agustus 2018 | Revisi: 23 Oktober 2018 | Dipublikasikan: 30 Oktober 2018 


\section{PENDAHULUAN}

Diabetes Melitus (DM) merupakan penyakit gangguan metabolik menahun akibat pankreas tidak memproduksi cukup insulin atau tubuh tidak dapat menggunakan insulin yang diproduksi secara efektif (Balitbangkes 2013). Pada saat ini Indonesia disebut-sebut telah bergeser naik, dari peringkat ke-7 menjadi peringkat ke-5 teratas diantara negaranegara dengan jumlah penderita DM terbanyak di dunia (Perkeni 2015). International Diabetes Federation menyatakan bahwa prevalensi DM di Indonesia pada tahun 2015 adalah 10 juta orang dan diperkirakan meningkat menjadi 16,1 juta orang pada tahun 2040 (IDF 2015). Jumlah penderita DM tertinggi saat ini ditemukan pada kelompok usia 40-59 tahun (sebanyak 166 juta jiwa), namun angkanya hampir setara dengan penderita berusia 60-79 tahun (sebanyak 164 juta jiwa). Perubahan demografi penting kaitannya dengan peningkatan prevalensi kasus DM di seluruh dunia yakni tingginya proporsi pada lansia (>65 tahun) (Bilous 2014).

Diabetes Melitus (DM) menjadi masalah kesehatan masyarakat utama karena komplikasinya bersifat jangka pendek dan jangka panjang. Hal ini berkaitan dengan kadar glukosa darah yang tinggi terus menerus (Bilous 2014). Secara umum, efek merugikan dari hiperglikemia adalah komplikasi makrovaskular (penyakit arteri koroner, penyakit arteri perifer, dan stroke) dan komplikasi mikrovaskular (nefropati diabetik, neuropati diabetik, dan retinopati) (Perkeni 2015).

Kondisi pasien DM yang bisa menjadi komplikasi inilah yang perlu diupayakan untuk dicegah. Diketahui juga bahwa penderita DM masih didominasi oleh usia lansia, dimana usia lansia sudah banyak mengalami kemunduran aktivitas fisiologis tubuh sehingga hal ini perlu mendapat perhatian. Hal inilah yang menjadi perhatian kami pada ibu-ibu komplek Depkes I Jatibening Bekasi. Komplek perumahan ini dihuni oleh lebih dari 70\% usia lansia karena usia komplek ini pun sudah lebih dari 35 tahun. Para orang tua yang hidup di komplek ini juga sudah banyak yang tinggal hanya berdua karena rata-rata anak-anak mereka sudah pindah dan berumah tangga masing-masing. Kegiatan kebersamaan yang banyak dilakukan di komplek ini lebih banyak dilakukan oleh para ibuibu. Selain itu ibu-ibu dapat menjadi media transformasi informasi yang baik terkait pengetahuan kesehatan dalam lingkungan keluarganya. Dengan demikian, ibu-ibu tersebut akan lebih terbekali dan terlatih dalam menjaga kesehatan keluarganya, sedangkan lansia 
merupakan kelompok usia yang dirasa perlu untuk diperhatikan kesehatannya melalui pendampingan terarah.

Berdasarkan hal tersebut, maka pada pengabdian masyarakat ini kami Tim Dosen Fakultas Farmasi Universitas Muhammadiyah Prof. Dr. HAMKA akan melakukan penyuluhan tentang penyakit diabetes melitus dan senam diabetes melitus pada ibu-ibu lansia di RT 04 dan RT 05 komplek Depkes I Jatibening Bekasi.

\section{MASALAH}

Muslim wajib berusaha semaksimal mungkin dalam menjaga kesehatannya baik kesehatan jasmani maupun rohani. Tubuh yang sehat akan sangat menunjang ibadah kita kepada Alloh SWT dan kegiatan kita sehari-hari, tak terkecuali usia lansia. Dengan bertambahnya usia, wajar saja bila kondisi dan fungsi tubuh pun makin menurun. Tak heran bila pada usia lanjut, semakin banyak keluhan yang dilontarkan karena tubuh tak lagi mau bekerja sama dengan baik seperti kala muda dulu.

Beberapa masalah yang kerap muncul pada usia lanjut, yang disebut sebagai a series of I's. Mulai dari immobility (imobilisasi), instability (instabilitas dan jatuh), incontinence (inkontinensia), intellectual impairment (gangguan intelektual), infection (infeksi), impairment of vision and hearing (gangguan penglihatan dan pendengaran), isolation (depresi), inanition (malnutrisi), insomnia (ganguan tidur), hingga immune deficiency (menurunnya kekebalan tubuh) (Sundari, 2016).

Sumber lain menyebutkan, penyakit utama yang menyerang lansia ialah hipertensi, gagal jantung dan infark serta gangguan ritme jantung, diabetes melitus, gangguan fungsi ginjal dan hati. Juga terdapat berbagai keadaan yang khas dan sering mengganggu lansia seperti gangguan fungsi kognitif, keseimbangan badan, penglihatan dan pendengaran (Sundari, 2016).

Seperti yang telah disebutkan bahwa jumlah penderita DM tertinggi saat ini ditemukan pada kelompok usia 40-59 tahun (sebanyak 166 juta jiwa), dan penderita berusia 60-79 tahun (sebanyak 164 juta jiwa) dimana usia tersebut termasuk usia lansia sehingga pengelolaan pasien DM ini harus menjadi perhatian tidak hanya tenaga kesehatan tetapi juga oleh penderita dan keluarga. Pengelolaan penyakit DM dikenal dengan empat pilar utama yaitu penyuluhan atau edukasi, terapi gizi medis, latihan jasmani atau aktivitas fisik dan intervensi farmakologis. 
Kegiatan pengabdian ini penting diberikan kepada mitra mengingat mitra adalah para lansia yang butuh informasi mengenai penyakit-penyakit sindrom metabolik yang terkait dengan mundurnya aktivitas metabolisme tubuh salah satunya adalah penyakit DM. Selain itu kualitas hidup pada para lansia perlu dijaga dengan aktivitas yang minimal namun dapat dikerjakan setiap waktu contohnya adalah dengan senam diabetes ini.

Hal inilah yang menjadi sasaran dari kegiatan ini yaitu dalam upaya preventif dan promotif melalui penyuluhan tentang penyakit DM serta latihan jasmani atau fisik melalui senam diabetes melitus di komplek Depkes I Jatibening Bekasi. Objek kegiata ini adalah para ibu-ibu kelompok lansia di RT 04 dan RT 05 komplek Depkes I Jatibening Bekasi.

Tujuan dilaksanakan kegiatan pengabdian masyarakat ini adalah upaya meningkatkan pemahaman dan pengetahuan tentang pentingnya pengetahuan mengenai penyebab, faktor resiko, dan gejala, serta upaya pencegahan komplikasi yang terkait dari penyakit diabetes melitus serta upaya promotif dan preventif komplikasi dengan senam diabetes kepada para ibu-ibu lansia di RT 04 dan RT 05 Komplek Depkes I Jatibening Bekasi. Dengan meningkatnya pemahaman dan pengetahuan hal tersebut, diharapkan mampu menumbuhkan kesadaran untuk pola hidup yang sehat di usia lansia sehingga mampu meningkatkan kesehatan dan kualitas hidup diri sendiri maupun dalam lingkungan keluarga mereka masing-masing.

\section{METODE PELAKSANAAN}

Metode yang digunakan untuk penyuluhan ini melalui ceramah tatap langsung dan berdiskusi dengan masyarakat mengenai definisi, faktor resiko, penyebab, gejala, serta cara pencegahan komplikasi penyakit diabetes melitus kemudian dilanjutkan dengan praktek langsung senam diabetes melitus.

Adapun tahap-tahap dari kegiatan ini adalah:

1. Pengisian kuisioner (pre-test)

Tahapan ini para peserta mengisi lembar kuisioner mengenai penyakit diabete melitus sebelum mendapatkan penjelasan dari penyuluh.

2. Ceramah

Tahapan ini para peserta diberi materi penyuluhan mengenai definisi, faktor resiko, penyebab, gejala, serta cara pencegahan komplikasi penyakit diabetes melitus.

3. Diskusi 
Tahapan ini para peserta diberikan kesempatan untuk berdiskusi dari materi yang telah disampaikan.

4. Praktek/simulasi senam

Tahapan ini para peserta diperlihatkan video mengenai senam diabetes melitus dilanjutkan simulasi atau praktek senam bersama.

5. Games/kuis dan pemberian doorprize

Tahapan ini peserta diberi games atau kuis jawaban singkat untuk me-recall materi yang telah disampaikan kemudian diberikan doorprize atau hadiah bagi peserta yang mampu menjawab.

6. Melakukan evaluasi kegiatan yang telah dilakukan.

Tahapan ini para peserta diberi lembar evaluasi (post-test) untuk mengevaluasi kegiatan yang sudah dilakukan.

7. Pemberian booklet diabetes melitus

Tujuan pemberian booklet adalah agar para peserta mempunyai buku panduan mengenai diabetes dan gerakan senam diabetes, sehingga kegiatan ini bisa dilanjutkan oleh peserta dan informasi mengenai diabetes yang terdapat di dalam booklet bisa disebarkan ke keluarga dan masyarakat disekitar tempat tinggal peserta

\section{PEMBAHASAN}

Kegiatan pengabdian dilakukan di dua mitra pengabdian yaitu ibu-ibu kelompok lansia RT 04 dan ibu-ibu kelompok lansia RT 05 komplek Depkes 1 Jatibening Bekasi. Pelaksanaan kegiatan dilakukan pada hari senin 23 Juli 2018 dengan menyewa sebuah gedung serbaguna di dalam komplek tersebut. Kegiatan ini dihadiri 11 orang ibu-ibu kelompok lansia RT 04 dan 12 orang ibu-ibu kelompok lansia RT 05. Sebelum dilakukan penyuluhan para peserta diberi lembar pre-test kuisioner.

Kegiatan pengabdian dilanjutkan dengan pemberian materi Diabetes Mellitus oleh tim meliputi penyuluhan berbentuk ceramah dan diskusi seputar definisi, faktor resiko, penyebab, gejala, serta cara pencegahan komplikasi penyakit diabetes melitus dilanjutkan diskusi materi. Pada sesi diskusi para peserta sangat antusias yang terukur dengan pesan dan kesan yang diberikan bahwa materi sangat menarik dan pemateri menguasai materi dengan sangat baik. Pengukuran tingkat kepahaman peserta dilihat juga dari kuisioner post-test. Dari total 23 peserta yang hadir hanya 16 peserta yang datanya lengkap pengisian 
kuisioner, sebagian yang lain karena keterbatasan fisik tidak mampu untuk menulis di kuisioner. Data peserta dapat dilihat pada Tabel 1.

Tabel 1. Hasil Kuisioner Pre-test dan Post-Test Tingkat Pengetahuan DM

\begin{tabular}{ccccccc}
\hline No & Umur & Jenis kelamin & Tk. Pendidikan & Pekerjaan & Pre-test & Post-test \\
\hline 1 & 63 & Perempuan & S1 & pensiunan & sedang & tinggi \\
2 & 53 & Perempuan & S1 & guru & sedang & sedang \\
3 & 59 & Perempuan & - & - & sedang & tinggi \\
4 & 68 & Perempuan & SMA & pensiunan dekpes & tinggi & tinggi \\
5 & 64 & Perempuan & - & - & tinggi & tinggi \\
6 & 68 & Perempuan & S1 & pensiunan & tinggi & tinggi \\
7 & 77 & Perempuan & S1 & pensiunan & tinggi & tinggi \\
8 & 63 & Perempuan & - & - & tinggi & tinggi \\
9 & 60 & Perempuan & SMA & - & tinggi & tinggi \\
10 & 57 & Perempuan & - & pensiunan & tinggi & tinggi \\
11 & 66 & Perempuan & SMA & pensiunan & tinggi & tinggi \\
12 & 63 & Perempuan & - & IRT & tinggi & tinggi \\
13 & 71 & Perempuan & SMA & IRT & sedang & sedang \\
14 & 54 & Perempuan & S1 & IRT & rendah & sedang \\
15 & 66 & Perempuan & - & - & tinggi & tinggi \\
16 & 62 & Perempuan & - & - & sedang & sedang \\
\hline
\end{tabular}

Berdasarkan hasil kuisioner pre-post test pada Tabel 1 terlihat satu orang peserta mengalami peningkatan dari tingkat pengetahuan rendah ke sedang, satu orang naik dari sedang ke tinggi, tiga orang tetap pada tingkat sedang, dan 11 orang yang lain punya pemahaman tinggi dari saat pre test hingga post test. Dari Tabel 1 ini terlihat bahwa tingkat pemahaman para peserta sangat baik tentang penyakit DM.

Analisa statistic uji Wilcoxon, dari data pre-post test (nilai P (0.083) dari 0.05) diketahui bahwa tidak ada peningkatan signifikan terhadap tingkat pengetahuan kelompok setelah dilakukan penyuluhan. Beberapa alasan diduga mendasari hal tersebut antara lain: (1) Tingkat pengetahuan responden awal sebagian besar (11 orang) sudah tinggi; (2) Tingkat pendidikan responden juga kebanyakan S1/sarjana (3) Karena berada di lingkungan komplek Depkes, rata-rata responden adalah pensiunan Depkes, dinkes, ataupun bpom dimana pusat pemerintahan tersebut terhubung langsung dengan lingkungan kesehatan. Namun, kegiatan ini dirasa sangat berkesan dan bermanfaat bagi para peserta penyuluhan yang terbukti dari kesan pesan yang diisi oleh peserta. Setelah penyuluhan, 
kegiatan dilanjutkan dengan simulasi/praktek langsung senam diabetes melitus. Peserta sangat antusias mempraktekkan senam diabetes yang terlihat dari antusiasme menggerakkan kakinya sambil menonton video maupun mempraktekkannya kembali saat pemberian doorprize. Dari praktek senam ini peserta juga akhirnya memahami salah satu olahraga sederhana untuk dapat mengatasi dan mencegah penyakit diabetes pada diri sendiri dan keluarga. Dengan demikian, diharapkan kegiatan semacam ini dapat berlanjut dan kembali dilaksanakan baik dengan mitra yang sama maupun mitra yang berbeda demi menciptakan masyarakat Indonesia yang peduli pada kesehatan melalui kegiatan promotif kesehatan berupa senam diabetes (senam kesehatan).

\section{KESIMPULAN}

Kegiatan kemitraan berupa penyuluhan seputar kepedulian kesehatan dan promotif/preventif kesehatan dirasa masih sangat dibutuhkan masyarakat terutama kalangan lansia. Para Ibu merupakan sasaran penyuluhan yang tepat karena merupakan pusat pemberian informasi kesehatan dalam keluarga. Dengan demikian, melalui kegiatan ini diharapkan mampu menjadi penambah pengetahuan dan wawasan masyarakat luas dalam hal kepedulian diri untuk menjaga kesehatan diri dan keluarga.

Kegiatan kemitraan semacam ini perlu dilakukan secara berkala dengan tema penyakit lain dan dengan metode yang kreatif serta inovatif sehingga menarik perhatian masyarakat untuk peduli pada kesehatan diri dan keluarga.

\section{UCAPAN TERIMA KASIH}

Terima kasih kepada LPPM (Lembaga Penelitian Pengabdian Masyarakat) sebagai pemberi dana kegiatan ini. Terima kasih kepada ibu-ibu kelompok lansia RT 04 dan RT 05 Komplek Depkes I Jatibening Bekasi.

\section{DAFTAR PUSTAKA}

Balitbangkes. 2013. Riset Kesehatan Dasar. Jakarta: Badan Penelitian dan Pengembangan Kesehatan Republik Indonesia.

Perkeni. 2015. Konsensus Pengelolaan Dan Pencegahan Diabetes Melitus Tipe 2 di Indonesia 2015. Jakarta: Perkumpulan Endokrinologi Indonesia.

IDF. 2015. International Diabetes Federation Diabetes Atlas-7th Edition. http://www.diabetesatlas.org. Diakses 10 januari 2018.

Bilous MDR. 2014. Buku Pegangan Diabetes Ed ke-4. Jakarta: Bumi Medika. 
Sundari, Sri. 2016. Laporan Pengabdian, Penyuluhan Tentang Penyakit Diabetes Melitus dan Osteoarthritis Di Dusun Kaliabu, Ambar Ketawang, Gamping, Sleman. Yogyakarta.

(C) 2018 Oleh authors. Lisensi Jurnal Solma, LPPM-UHAMKA, Jakarta. Artikel ini bersifat open access yang didistribusikan di bawah syarat dan ketentuan Creative Commons Attribution (CC BY) license (http://creativecommons.org/licenses/by/4.0/). 